\title{
How Have Banks Been Managing the Composition of High-Quality Liquid Assets?
}

\author{
Jane Ihrig, Edward Kim, Cindy M. Vojtech, and Gretchen C. Weinbach
}

Banks' liquidity management practices are fundamental to understanding the implementation and transmission of monetary policy. Since the Global Financial Crisis of 2007-09, these practices have been shaped importantly by the liquidity coverage ratio requirement. Given the lack of public data on how banks have been meeting this requirement, we construct estimates of U.S. banks' high-quality liquid assets (HQLA) and examine how banks have managed these assets since the crisis. We find that banks have adopted a wide range of HQLA compositions and show that this empirical finding is consistent with a risk-return framework that hinges on banks' aversion to liquidity and interest rate risks. We discuss how various regulations and business model choices can drive HQLA compositions in general, and connect many of the specific compositions we see to banks' own public statements regarding their liquidity strategies. Finally, we highlight how banks' preferences for the share of HQLA met with reserves affect the Fed's monetary policy implementation framework. (JEL E51, E58, G21, G28)

Federal Reserve Bank of St. Louis Review, Third Quarter 2019, 101(3), pp. 177-201.

https://doi.org/10.20955/r.101.177-201

\section{INTRODUCTION}

Liquidity management-ensuring access to sufficient quantities of assets that can be converted easily and quickly into cash with little or no loss of value-has always been a key component of banks' balance sheet management. However, liquidity management has become an even more important consideration in banks' operations in the wake of the Global Financial Crisis of 2007-09 with the introduction of new regulations aimed at ensuring banks' ability to meet their cash and collateral obligations during times of financial stress. In particular, beginning in 2015, large banks in the United States have needed to comply with the liquidity coverage ratio (LCR) by holding sufficient "high-quality liquid assets" (HQLA), a requirement

Jane Ihrig is an economist and senior advisor, Edward Kim was a research assistant, Cindy M. Vojtech is a principal economist, and Gretchen C. Weinbach is an economist and senior associate director at the Board of Governors of the Federal Reserve System. The authors thank Roop Ambardekar for his initial help with the data, Akber Khan for his excellent research assistance, and Ashish Kumbhat for his input on an earlier version of this article. They also thank seminar participants at the Board of Governors of the Federal Reserve System, the Federal Reserve Bank of New York, and the MBAA International 2018 conference.

(c) 2019, Federal Reserve Bank of St. Louis. The views expressed in this article are those of the author(s) and do not necessarily reflect the views of the Federal Reserve System, the Board of Governors, or the regional Federal Reserve Banks. Articles may be reprinted, reproduced, published, distributed, displayed, and transmitted in their entirety if copyright notice, author name(s), and full citation are included. Abstracts, synopses, and other derivative works may be made only with prior written permission of the Federal Reserve Bank of St. Louis. 
that has induced significant changes to banks' balance sheet management. In this article, we examine how U.S. banks have managed the composition of their HQLA to meet the LCR and other liquidity considerations over the past several years. $\frac{1}{}$ In particular, we address the following questions: Which particular liquid assets have banks chosen to hold and in what shares? Have those liquid shares changed over time? Do banks' preferences for these liquid shares vary? If so, what factors may be driving banks' preferences in this regard?

Understanding banks' liquidity management is central to both the implementation and the transmission of monetary policy. Banks' preferences regarding the compositions of their liquid pools-and in particular their demand for excess reserve balances-interact with various short-term market interest rates and thus the Federal Reserve's setting of its administered rates. In turn, the constellation of these interest rates affects banks' choices regarding the composition of their balance sheets-that is, the trade-off between lending and holding liquid assets-and hence the transmission of monetary policy (Bianchi and Bigio, 2017). In addition, we and others have noted that banks' preferences regarding the compositions of their liquid assets have influenced the Federal Open Market Committee's determination of "ample" reserves needed to effectively and efficiently implement monetary policy in the longer run; ultimately, these preferences affect the long-run size of the Federal Reserve's balance sheet. $\underline{\text { ? }}$

Because no historical time series of HQLA are available, we begin our analysis by constructing bank-level, quarterly estimates of HQLA from 1997 to the present. We focus on the three largest components of HQLA - banks' reserve balances held at the Federal Reserve and their holdings of both Treasury securities and certain mortgage-backed securities (MBS). We use our bank-level estimates to document how U.S. banks have managed the compositions of their HQLA pools over time. Not surprisingly given the Federal Reserve's large-scale asset purchases (LSAPs) that injected reserves into the banking system at the time, we find that during the run-up to becoming LCR compliant, banks in aggregate took on a significant quantity of excess reserves. However, after becoming compliant, many such banks adjusted their liquid asset holdings, reducing their stocks of reserve balances and raising their holdings of other HQLA components, presumably to achieve a more optimal configuration.

To explain this subsequent compositional adjustment, we use a risk-return framework that captures the relative return of the different HQLA components, the covariance of these returns, and the sensitivity of banks' preferences for these assets to a metric of their risk aversion. One can think of this model as capturing the decisions of a bank's treasury department. The bank treasurer oversees investments in various securities and cash instruments while providing for the bank's daily liquidity needs and meeting regulatory constraints such as the LCR. In particular, in managing the bank's liquid assets, the treasurer considers liquidity riskthe risk that cash is not immediately available when needed-and interest rate risk-in this case, the risk that the value of a liquid asset will change due to a change in interest rates. Interest rate risk is a particular concern for holders of fixed-income securities such as Treasury securities. The more risk averse the bank is in this context, the more its treasury department tilts its bank's HQLA composition toward cash—that is, the more the bank prefers holding a relatively high share of reserve balances in its HQLA pool, helping to insulate it from both liquidity and interest rate risks. 
With this model in hand, we then look at individual, bank-level data for the eight U.S global systemically important banks (GSIBs) based on publicly available sources. We find that the HQLA compositions of these large institutions differ widely, with some institutions relying on reserves and others more so on longer-term assets. This result holds even for some institutions with similar business models. Digging deeper with daily, bank-reported confidential HQLA data, we find that the volatilities of these banks' HQLA shares differ. In particular, we find that banks that exhibit a relatively higher level of daily volatility in their cash balances tend to rely more heavily on reserves to meet their liquidity needs.

We conclude that banks have different tolerances for exposure to liquidity and interest rate risks, and, based on research into individual banks' own descriptions of their liquidity management strategies, we identify a number of factors influencing their strategies. These factors include their individual evaluations of how they choose to meet post-crisis financial regulations as well as a range of other influences including differing business models, products and services, and unobservable, internal operating procedures. Where possible, we back up our empirical findings with specific public statements. For example, large banks have cited resolution planning requirements-which rely on bank-dependent stress-test models-as a key driver of their reserves share of HQLA.

The remainder of this article proceeds as follows. Section 2 positions our work in the related literature. Section 3 provides background information about the LCR and HQLA and describes the two different sets of time-series data that we construct. Using those data, Section 4 describes how banks initially adjusted, and then subsequently managed, the compositions of their HQLA. Section 5 introduces our model, and Section 6 explores our banklevel estimates for the eight GSIBs, including the ranges of both the sizes and volatilities of these banks' HQLA shares. Section 7 highlights key factors that drive banks' decisionmaking regarding their HQLA shares and summarizes the differences evident across the GSIBs. Section 8 concludes.

\section{RELATED LITERATURE}

Given that international-based regulatory liquidity requirements are relatively new for the banking industry, research regarding how banks are adjusting to these post-crisis regulations is nascent and growing. For example, Allen (2014) and Diamond and Kashyap (2016) survey the existing literature and generally conclude that more research is needed to understand the effects of liquidity regulation on banks' behavior.

That said, our work is complementary to a few studies. Banerjee and Mio (2015) describe their work as being the first study to estimate the causal effect of liquidity regulation on banks' balance sheets. They examine the impact on banks' balance sheets of the implementation of a new LCR-like requirement in the United Kingdom and find that U.K. banks adjusted the compositions of both their assets and liabilities at the onset of the new requirement, including increasing HQLA. Our findings are similar in that we document an increase in U.S. banks' holdings of HQLA in response to new U.S. liquidity regulation. Our study differs in that we also consider how banks subsequently managed the compositions of their liquid assets once initially becoming regulatory compliant. 
Cetina and Gleason (2015) use examples to show how compositional asset and liability caps in the U.S. LCR rule introduce nonlinearities in the calculation of the ratio and conclude that banks' LCRs can vary in complex ways not necessarily related to underlying liquidity risk. In our analysis, we also account for the nonlinearity of the LCR's asset caps in our model estimates. However, our work differs from that study in that we focus on the compositional shares of HQLA and abstract from issues associated with the computation of the LCR itself.

Balasubramanyan and VanHoose (2013) use a theoretical model to examine how the LCR is likely to affect banks' balance sheet dynamics and conclude that the LCR may generate bank responses that are not necessarily fully consistent with a policy objective of greater stability of bank deposits and loans. Our study differs in that we focus on a different slice of banks' balance sheets-HQLA portfolios-and explain how such holdings have evolved in light of the LCR and why that may be the case.

Other LCR-related research includes theoretical work that explores the interaction between liquidity regulation and monetary policy (Bech and Keister, 2017, and Duffie and Krishnamurthy, 2016) and dynamic general equilibrium models that explore the interactions between banks' responses to liquidity and capital regulations (Adrian and Boyarchenko, 2013, and Covas and Driscoll, 2014). Our article adds to the literature on theoretical approaches to studying the effects of liquidity regulation on bank behavior by using a risk-return framework to help motivate banks' preferences for the compositions of their HQLA portfolios.

Next we review key aspects of the U.S. LCR requirement, including why it was implemented, and then describe how we compute our time-series estimates of bank-level HQLA.

\section{BACKGROUND AND DATA CONSTRUCTION}

During the Global Financial Crisis of 2007-09, substantial stress in U.S. funding marketsilliquidity-caused solvency issues for several large financial institutions. With financial markets quite fragile, funding shocks easily spread across the financial system. In the wake of the crisis, international financial regulators sought to improve the resiliency of the financial system by incorporating liquidity requirements into the international Basel III framework for enhanced regulation of banking institutions. Basel III is a comprehensive set of reform measures, developed by the Basel Committee on Banking Supervision (BCBS), to strengthen the regulation, supervision, and risk management of the banking sector. - One key liquidity measure, and the focus of this article, is the LCR.

The LCR aims to strengthen the liquidity positions of financial institutions by creating a standardized minimum daily liquidity requirement for large and internationally active banking organizations. ${ }^{4}$ In particular, relative to the pre-crisis period, the LCR requires that bank holding companies (BHCs) maintain ready access to a pre-determined minimum level of highly liquid assets to meet demand for cash over the short term, a rolling 30-day period. (In this article, we will use the terms "BHCs" and "banks" interchangeably.) The formula for calculating the LCR is generally represented by equation (1):

$$
L C R=\frac{H Q L A}{\text { Estimated net cash outflows }} \geq 100 \%
$$


Ihrig, Kim, Vojtech, Weinbach

The numerator of the ratio, HQLA, is made up of a range of liquid assets grouped into categories according to their approximate "level" of liquidity, or ease of conversion to cash. "Level 1" assets, the first column in Table 1, comprise the most liquid forms of HQLA, free of haircuts and limiting compositional caps. This category includes excess reserves and securities issued or guaranteed by the U.S. government. Excess reserves are balances held at Federal Reserve Banks in addition to any that banks must hold to meet reserve requirements against their deposit liabilities. The allowable securities in the Level 1 asset category include U.S. Treasury securities, Government National Mortgage Association (GNMA) MBS, and obligations issued by U.S. government agencies (or "non-GSE [government-sponsored enterprise] agency debt"). U.S. government agencies (non-GSEs) include the GNMA, the FDIC, and the Small Business Administration.

"Level 2" assets, which cannot account for more than 40 percent of total HQLA, comprise two subcategories:

- Level 2A assets, the second column in Table 1, are subject to a 15 percent haircut and include securities issued or guaranteed by a U.S. GSE, such as GSE debt securities as well as these institutions' residential MBS and commercial MBS (CMBS). (U.S. GSEs are defined in the Table 1 note.)

- Level 2B assets (not shown), which include corporate debt securities and tend to comprise a much smaller portion of banks' balance sheets, are subject to a substantial haircut (50 percent) and can be no more than 15 percent of total HQLA. Without loss of generality, we abstract from these assets in our analysis. $\underline{5}$

Of the various HQLA assets, banks in aggregate hold the largest amounts of excess reserves, Treasury securities, and GSE MBS, the highlighted cells in Table 1 and the predominant focus of our analysis.

A bank's size and the degree of its international exposure determine which of two required LCR stringency levels it must meet. The largest banking organizations are subject to the "standard" LCR rule (hereafter, standard LCR banks or standard BHCs). At year-end 2017, 15 U.S. banks were in this category. Smaller banking organizations are subject to a less stringent, "modified" LCR rule (hereafter, modified LCR banks or modified BHCs). $\underline{6}$ At the end of 2017, 22 banks were in this category, but we excluded 5 such institutions from our sample because of their insufficient time spent in the category or because they underwent a significant structural change during the sample period. Thus, our sample includes 15 standard LCR banks and 17 modified LCR banks. For comparison, we also consider banks not subject to the LCR requirement over our period of study ("non-LCR banks"). Note that for all analysis in this 
article, we keep each bank's LCR membership_standard, modified, or neither-fixed across time based on its year-end 2017 status.

Although the largest U.S. banks began publicly disclosing a limited set of metrics related to the LCR requirement in the second quarter of 2017, data for periods prior to that time were not required to be reported. In addition, while some large banks began publically disclosing their LCRs as early as early 2014 during events such as quarterly earnings conference calls and other investor presentations, they did so without releasing the detailed data that underlie the ratio. Here, using a range of data sources, we construct two different time series of banks' HQLA holdings. The first is a quarterly series based on publicly available data sources. The second is a daily series based on confidential supervisory data reported to the Federal Reserve. Our proxy HQLA series allow us to analyze which assets these institutions chose to hold to satisfy their LCRs over time. The data appendix provides a full description of our data sources, both public and confidential, as well as our calculation methods and assumptions made for simplicity or due to data limitations; we describe in subsequent sections how we take asset haircuts and caps into account.

As we show in the next section, although the deadline for banks' full LCR compliance was phased in between January 2015 and January 2017, banks' balance sheet management was affected well before this period. $\underline{7}$

\section{HOW DID BANKS INITIALLY INCREASE AND THEN SUBSEQUENTLY MANAGE THEIR HQLA?}

Figure 1 shows our quarterly time-series measure of standard LCR banks' aggregate HQLA (total holdings of HQLA, abstracting from the LCR's haircuts and compositional caps) and each of the three key components of HQLA highlighted in Table 1-reserve balances, Treasury securities, and GSE MBS.. For comparison, we also show GNMA MBS, a much less widely held Level 1 component of HQLA. Each of the five data series is plotted as a share of these banks' total assets. Looking at the key LCR-related announcement dates (vertical bars), one sees that in the years leading up to the initial deadline for LCR compliance (January 2015), these institutions substantially increased the shares of liquid assets on their balance sheets, particularly in 2013 and 2014, and did so primarily by taking on substantial reserve balances (blue-dashed line).

It is important to remember that accumulating reserve balances over this period was easy for banks; in fact, it was not a choice for the banking sector as a whole. Prior to the Financial Crisis, the amount of reserve balances in the banking system was consistently quite smallthat is, prior to 2008, the blue-dashed line is very close to zero. However, as a result of the Federal Reserve's LSAPs, which were conducted between 2009 and 2014 (gray-shaded regions), reserve balances grew over many quarters at varying rates. ${ }^{9}$ In total, the amount of reserves in the banking system increased by over $\$ 2$ trillion as a result of the Federal Reserve's LSAPs.

The figure also illustrates that standard LCR banks actively acquired other HQLA-eligible securities in the lead-up to the full-compliance deadline (January 2017). In particular, the share of these institutions' holdings of Treasury securities (green line) rose over 2014 and 


\section{Figure 1}

\section{Major Components of High-Quality Liquid Assets at Standard LCR Banks}

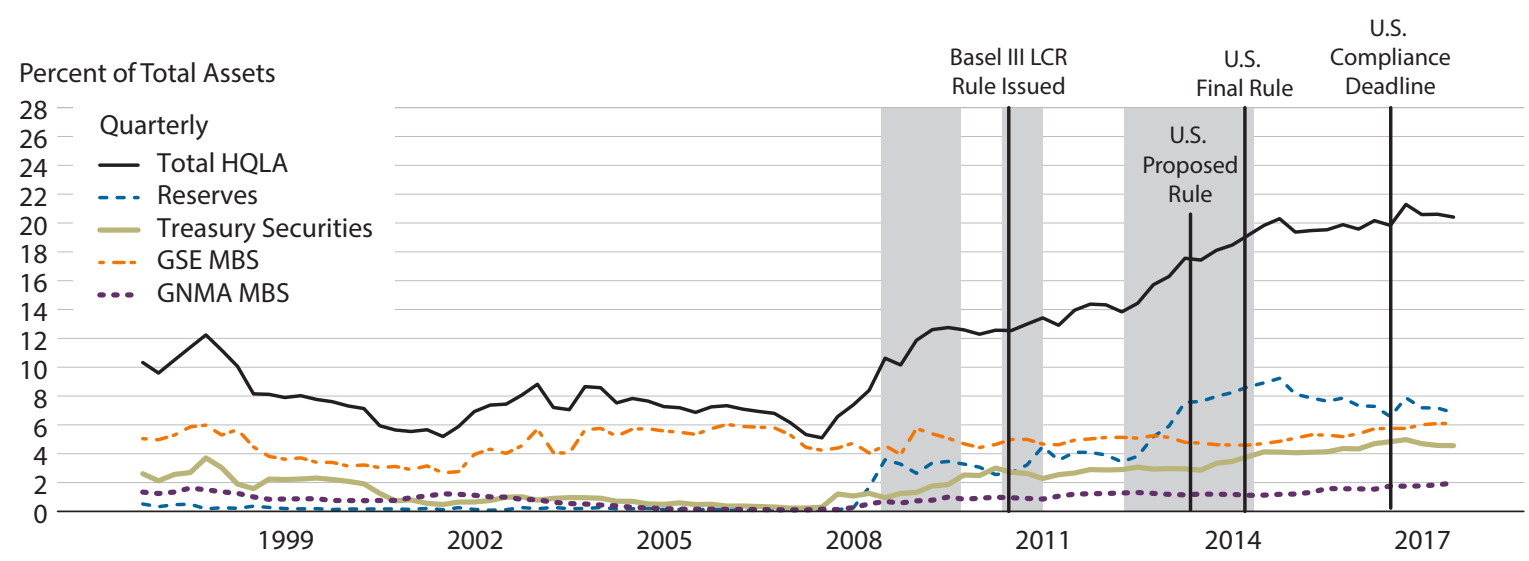

NOTE: Standard LCR banks are defined as BHCs with $\$ 250$ billion or more in total assets or $\$ 10$ billion or more in on-balance sheet foreign exposures. Shaded bars indicate periods of the Federal Reserve's LSAPs. See the data appendix for explicit line items used to construct the categories. SOURCE: FR Y-9C, FR 2900 (for reserve balances).

Figure 2

\section{Major Components of High-Quality Liquid Assets at Modified LCR Banks}

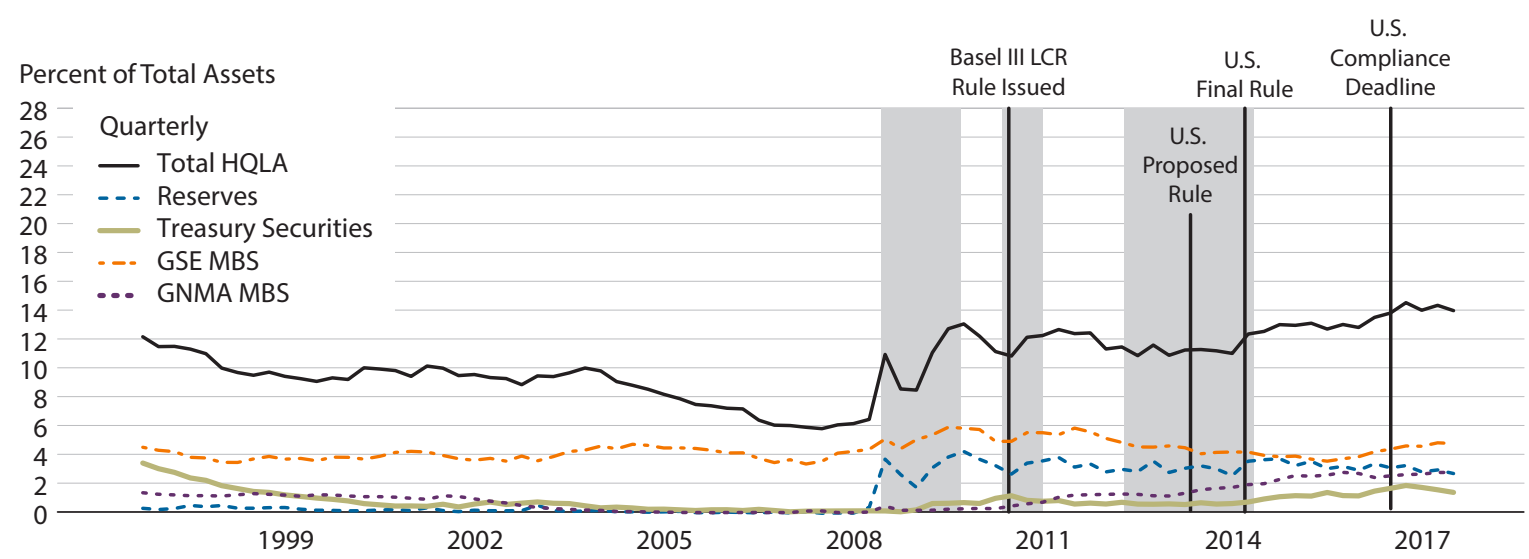

NOTE: Modified LCR banks are defined as BHCs with $\$ 50$ billion or more in total assets. Shaded bars indicate periods of the Federal Reserve's LSAPs. See the data appendix for explicit line items used to construct the categories.

SOURCE: FR Y-9C, FR 2900 (for reserve balances). 


\section{Figure 3}

\section{Comparing Shares of Selected HQLA-Eligible Assets by Bank Group (units as a percent of HQLA)}
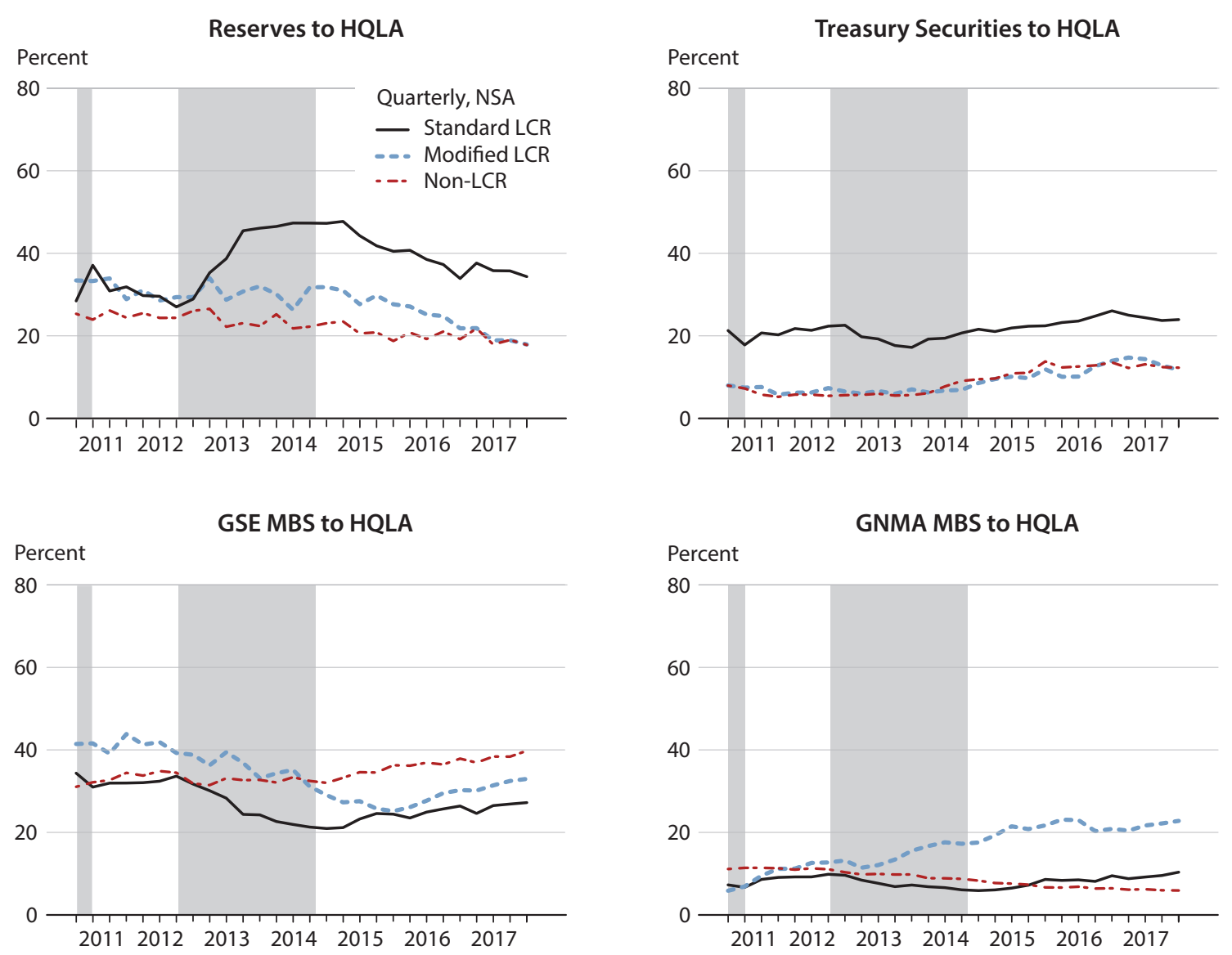

NOTE: NSA, not seasonally adjusted. Reserves defined as balances held at Federal Reserve Banks as reported in Federal Financial Institutions Examination Council (FFIEC) Call Reports. Only reserve balances held in excess of required amounts are HQLA eligible. All other data are from the FR Y-9C. Security balances are based on fair values for available-for-sale (AFS) and held-to-maturity (HTM) securities, as well as securities held in trading accounts. Shaded bars indicate periods of the Federal Reserve's LSAPs. See the data appendix for explicit line items used to construct the categories. SOURCE: FR Y-9C and Call Reports (FFIEC 031/041).

continued to grow, on balance, thereafter. In addition, the share of these banks' holdings of GSE MBS (orange-dashed line) also increased over most of that same period. Meanwhile, these banks' holdings of GNMA MBS (purple-dashed line) stayed relatively low and flat as a share of total assets.

Figure 2 reports similar data for the set of modified LCR (smaller) banks. Here we see a very different pattern. These banks' reserve holdings as a share of total assets (blue-dashed line) were roughly steady from the time of the issuance of the Basel III rule through the end of 2016. In contrast to the standard LCR banks, over that same period, these firms mostly increased their holdings of GNMA MBS (purple-dashed line), a Level 1 asset, and also increased their holdings of Treasury securities. 
Of course, another important difference between the two sets of banks is that the modified LCR banks needed to undertake a much smaller overall buildup of HQLA: At the end of 2017, the HQLA of modified LCR banks were about 14 percent of total assets (black line), while those for standard LCR banks were about 20 percent. This differential is approximately accounted for by the differential treatment of the denominator of the modified LCR rule (see endnote 6).

Next we compare the behavior of the two LCR bank groups just discussed side by side with similar data for the set of non-LCR banks. In particular, Figure 3 shows each of the same four HQLA components-reserves, Treasury securities, GSE MBS, and GNMA MBS—but now as a share of total HQLA (instead of total assets) for standard LCR banks (black lines), modified LCR banks (blue-dashed lines), and non-LCR banks (red-dashed lines). The same component contours described above for the LCR banks are apparent. Meanwhile, the liquidasset holdings of non-LCR banks remained relatively flat during the period of transition to meet the liquidity requirement, suggesting that the LCR was in fact an important driver of banks' balance sheet management over that period.

Banks likely faced somewhat different incentives in the run-up to becoming LCR compliant than they subsequently faced. In the run-up, Wall Street analysts were regularly asking about banks' progress and some institutions began publicly reporting updates; as a result, banks may have felt some pressure to build a sufficient stock of HQLA to become compliant. If so, managing the composition of HQLA over that period may not have been banks' top priority.

But in 2015 and 2016, after standard LCR banks first met initial LCR compliance, total HQLA generally leveled off-HQLA comprised about 20 percent of the total assets of standard LCR banks at the end of 2014 and remained in that neighborhood thereafter (see Figure 1). During this period, banks' primarily made compositional adjustments to their HQLA. In particular, reserves comprised 47 percent of standard LCR banks' HQLA at the end of 2014 and then declined by about 13 percentage points (see Figure 3). .0 Meanwhile, the GSE MBS and Treasury shares at these same institutions each increased. Similarly, as noted above, modified LCR banks also adjusted the compositions of their HQLA after meeting initial LCR compliance, increasing their shares of both GNMA MBS and Treasury securities. Moreover, all of these institutions continued to adjust their HQLA compositions once the deadline for full LCR compliance passed, generally reducing their shares of Treasury securities in favor of holding additional MBS.

This reshuffling of banks' HQLA raises the question, What drives banks' decisionmaking regarding their desired shares of HQLA? The next section addresses this question using a risk-return framework.

\section{TO WHAT EXTENT DOES A RISK-RETURN TRADE-OFF EXPLAIN BANKS' HQLA SHARES?}

We begin by thinking about an active bank treasurer who needs to invest cash to maximize the bank's risk-adjusted return on its asset holdings and at the same time ensure sufficient funds are available for the institution's liquidity needs. A bank's liquidity needs can stem both from external regulatory constraints - such as the LCR and resolution-planning requirements- 
and from self-imposed internal controls and preferences regarding liquidity and capital or other aspects of the bank's balance sheet management. In managing its liquidity needs, the bank treasurer accounts for both liquidity risk and interest rate risk. $\underline{11}$

Our risk-return framing contrasts with an approach in which a bank's choice of HQLA is modeled in the context of its portfolio value at risk, such as in Cuoco and Liu (2006). Value at risk is a statistical technique used to estimate the quantity of potential losses on an entity's investment portfolio over a specific timeframe. Such an approach is useful when the focus of study is banks' potential for realizing losses and the extent of those potential losses, particularly on relatively risky assets, such as those whose market pricing tends to be highly volatile, or on various other exposures such as foreign currency or derivatives positions. Instead, we focus on banks' holdings of highly liquid assets and on explaining the risk-return and other trade-offs that banks face in choosing the optimal allocations of such assets. Our modeling is similar to Halaj $(2013,2016)$, who focuses on a bank's optimal risk-return problem; there, however, the focus is on banks' entire balance sheets in context of stress testing.

In our model, we assume a bank allocates HQLA across three assets-reserve balances, Treasury securities, and GSE MBS. Reserves are guaranteed to have the same principal value returned the next day, and these balances receive a fixed overnight return. Therefore, this asset carries no liquidity, interest rate, or credit risk, and we consider it the risk-free asset. We also assume that each individual bank can choose the level of reserve balances it wishes to hold. Of course, the Federal Reserve determines the aggregate quantity of reserve balances available to the banking system. Stated another way, while an individual bank may adjust its holdings of reserves, the banking system as a whole cannot.

Unlike reserve balances, the day-to-day value of, and returns on, Treasuries and MBS vary as their market prices adjust with current and expected future financial market conditions, including the likely future paths of interest rates. A bank treasurer may wish to reduce the liquidity and interest rate risks associated with its liquid portfolio for a number of reasons. For example, a bank may want more certainty regarding the value of its liquid portfolio, more immediate accessibility to its liquid assets on hand, or to limit unwanted volatility in its regulatory capital stock through marked-to-market changes in its liquid securities holdings. $\underline{12}$ Keep in mind that transactions to obtain cash by selling a security or by lending a security through a repurchase agreement (repo) do not settle until the following day, and the ultimate proceeds raised from such transactions depend on conditions in financial markets on a given day. To reduce interest rate risk from Treasury holdings, securities of shorter tenors can be purchased. But such a step will not completely eliminate the market price volatility of these holdings. Regarding MBS, while shorter tenors can also be used to manage interest rate risk, the duration of MBS generally lengthens when interest rates rise because mortgage prepayments tend to decline in that situation. As a result, interest rate risk can be higher for MBS than Treasury securities, even if the securities pay the same coupon rate. And both Treasuries and MBS carry some liquidity risk, as a repo or sales transaction is needed to monetize these assets. $\underline{13}$ Overall, banks have to determine the share of HQLA they want to hold in the form of reserves - the risk- free asset with a lower average return-versus these longer-term assets that yield higher average returns but carry varying degrees of liquidity and interest rate risks. 
This model is consistent with bank treasurers' own descriptions of their HQLA management. 14

To determine a bank's optimal liquid portfolio, we first solve for the optimal "risky" HQLA portfolio (denoted with subscript $R$ ) - that is, the share of Treasury securities and MBS-that maximizes the risk-return trade-off captured by the Sharpe ratio shown in equation (2):

$$
\text { Sharpe ratio }=\frac{E\left(r_{R}\right)-r_{R B}}{\sigma_{R}},
$$

where $E\left(r_{R}\right)$ is the expected return of the risky portfolio, $r_{R B}$ is the risk-free rate on reserve balances, and $\sigma_{R}$ is the standard deviation of the risky portfolio. Daily returns are used to make these calculations.

After determining the optimal risky HQLA portfolio, a specific bank's complete HQLA portfolio (denoted with subscript $P$ ) will depend on its aversion to liquidity and interest rate risks, which is captured in parameter $A$ in equation (3):

$$
U\left(r_{P}\right)=E\left(r_{P}\right)-\frac{1}{2} A \sigma_{P}^{2}
$$

where

$$
\begin{gathered}
E\left(r_{P}\right)=(1-w) * r_{R B}+w * E\left(r_{R}\right), \\
\sigma_{P}^{2}=w^{2} * \sigma_{R}^{2},
\end{gathered}
$$

and $w$ is the share of risky assets. The higher a bank's value of $A$, the more risk averse it isthat is, the more it prefers a high share of reserves (cash) in its holdings of HQLA.

The curve in Figure 4 provides a stylized illustration of the efficient frontier that represents the optimal share of Treasury securities and MBS holdings—-the risky portfolio-for given risk-return trade-offs. When a risk-free asset is introduced, the straight line shown in the figure, known as the capital allocation line (CAL), is the new efficient frontier for the complete portfolio. The line's vertical intercept represents a portfolio that contains only the risk-free asset. The red dot designates the optimal risky portfolio. All points on the line between these two corner solutions represent portfolios that allocate some funds to both the risk-free asset and the optimal risky portfolio. Where a bank ends up on that line depends on its aversion to liquidity and interest rate risks-its value of $A$.

In solving for a bank's optimal portfolio shares, we use one representative Treasury security and one representative GSE MBS security in the analysis. $\frac{15}{}$ Information on the maturity of banks' securities holdings is not available through publicly available sources, so we use the Federal Reserve's confidential Complex Institution Liquidity Monitoring Report (FR 2052a) data as described in the data appendix to compute the average maturity of securities held by large banks. The maturity buckets collected are not sufficiently granular to distinguish among specific maturity holdings of Treasury securities or MBS, but we do see that the largest banks tend to hold securities of these types that mature in five or more years. Therefore, we assume that the market yields on 5-year constant maturity Treasury securities and 5- and 10-year 
Figure 4

\section{The Standard Investment "Efficient Frontier"}

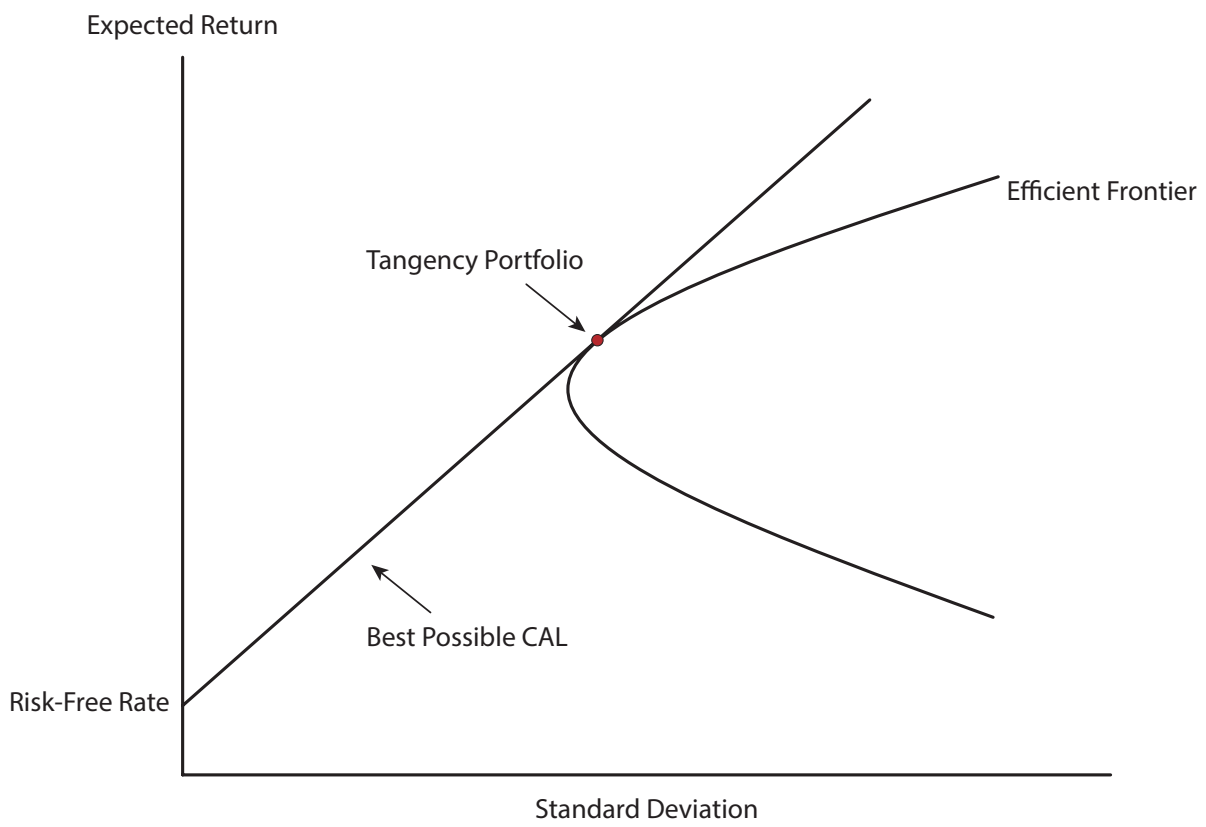

NOTE: This figure illustrates the construction of an optimal portfolio of assets given the efficient frontier of risky assets and the inclusion of a risk-free asset. The CAL is constructed by connecting the risk-free rate ( $y$-axis) to the tangency of the efficient frontier, which is the optimal risky portfolio.

constant maturity MBS (Fannie Mae) are the best available proxies for the returns on the two risky assets in our model portfolio.

We let the level of the risk aversion parameter, $A$, vary from 1 (relatively risk tolerant) to 10 (relatively risk averse). $\underline{16}$ In our setting, a relatively risk averse bank prefers little liquidity or interest rate risk. Aversion to interest rate risk corresponds with a desire for protection from volatility in interest rates-or, in terms of fixed-income securities, volatility of the market pricing-associated with the bank's HQLA portfolio. A bank's aversion to interest rate risk in this context will depend in part on the extent to which it wants to reduce the effects of any mark-to-market volatility in its securities holdings on its regulatory capital measures. For example, relative to a bank with a large regulatory cushion, a bank that is operating close to its regulatory minimum leverage ratio may not want much market price volatility associated with its assets and, therefore, will have a relatively higher value of $A$. Separately, a bank that protects itself from liquidity risk by assuming higher haircuts than its competitors do for internal stress-testing purposes, such as in the context of its resolution planning, will also have a relatively higher value of $A$.

Regarding our sample period, to start, we consider a recent period, 2012 through 2016, in which the size of the Federal Reserve's balance sheet was large and held constant. In this case, our model suggests that a bank treasurer should not want to hold any amount of the 


\section{Table 2}

\section{Optimal Portfolio Composition Using Data from 2001 to 2016}

\begin{tabular}{|c|c|c|c|c|c|c|}
\hline \multirow[b]{2}{*}{$\begin{array}{c}\text { Bank's risk } \\
\text { aversion }(A) \\
(1)\end{array}$} & \multicolumn{2}{|c|}{$\begin{array}{l}\text { Maturity of the two } \\
\text { "risky" assets }\end{array}$} & \multicolumn{4}{|c|}{ Portfolio compositions (optimal portfolio shares, \%) } \\
\hline & $\begin{array}{c}\text { Treasury } \\
\text { securities } \\
(2)\end{array}$ & $\begin{array}{c}\text { GSE MBS } \\
\text { (3) }\end{array}$ & $\begin{array}{c}\text { Reserves } \\
\text { (4) }\end{array}$ & $\begin{array}{c}\text { Treasury } \\
\text { securities } \\
(5)\end{array}$ & $\begin{array}{c}\text { GSE MBS } \\
(6)\end{array}$ & $\begin{array}{c}\text { Total } \\
\text { (by definition) } \\
\text { (7) }\end{array}$ \\
\hline \multirow{2}{*}{$\begin{array}{l}\text { High risk aversion } \\
\qquad(A=10)\end{array}$} & \multirow{6}{*}{5 year } & 5 year & 79 & 0 & 21 & 100 \\
\hline & & 10 year & 40 & 20 & 40 & 100 \\
\hline \multirow{2}{*}{$\begin{array}{l}\text { Middle of range } \\
\qquad(A=5)\end{array}$} & & 5 year & 59 & 1 & 40 & 100 \\
\hline & & 10 year & 15 & 45 & 40 & 100 \\
\hline \multirow{2}{*}{$\begin{array}{l}\text { Low risk aversion } \\
\qquad(A=1)\end{array}$} & & 5 year & 0 & 60 & 40 & 100 \\
\hline & & 10 year & 0 & 60 & 40 & 100 \\
\hline
\end{tabular}

risk-free asset-reserve balances. This holds for all considered values of the risk aversion parameter, $A$. In fact, given the relatively high return on GSE MBS and these securities' limited volatility, each institution in this case prefers to hold all of its liquid assets in MBS. But, as noted above, there is a limit to the amount of Level 2 assets that may be used to satisfy the LCR; because no more than 40 percent of a bank's HQLA holdings may consist of such assets, the optimal composition of HQLA in this case is 60 percent Treasury securities and 40 percent GSE MBS. 17

However, one may think that during this period the volatility in market interest rates was significantly constrained by their proximity to the zero lower bound and, given that our model relies on the relationship between asset returns and covariances, that this circumstance could bias our model results away from holding the risk-free asset toward holding a riskier portfolio. Therefore, we also consider the longer period from 2001 to 2016, which embodies much more variability in the returns on liquid assets. Because the Federal Reserve began paying interest on reserve balances during this longer period-in late 2008-we assume the risk-free asset is remunerated at the effective federal funds rate prior to the onset of interest on reserves. This assumption can be interpreted as one in which the Federal Reserve's pre-crisis monetary policy implementation framework was a corridor system that paid interest on excess reserves. 18

For this longer time period, we do find demand for the risk-free asset. As shown in Table 2, the share of reserves in a bank's optimal HQLA portfolio (column 4) varies widely depending on the bank's assumed degree of risk aversion (column 1). For example, when a bank's risk aversion is high (that is, $A=10$; first pair of rows ), the optimal share of reserves ranges from 40 percent to about 80 percent of the bank's total HQLA, depending on the securities considered. In contrast, when a bank's risk aversion is assumed to be low ( $A=1$; bottom pair of rows), the optimal share of reserves is zero regardless of the other securities considered. We conclude that our model supports a fairly wide range of plausible liquid portfolio compositions.

These results have implications for the Federal Reserve's longer-run supply of reserves in the banking system. The LCR requirement has effectively caused a structural change by boost- 
ing banks' demand for highly liquid assets relative to the pre-crisis period. This change means that, relative to the pre-crisis period, for any given level of the federal funds rate, more excess reserves may be needed in the banking system to meet the LCR requirement. This finding is consistent with the Board of Governors of the Federal Reserve System's September 2018 Senior Financial Officer Survey where large banks responded that regulatory factors are important determinants of their demand for reserves. $\frac{19}{}$ That said, asset substitutability will also importantly be driven by interest rate differentials. If the yield on Treasury securities or GSE MBS is sufficiently higher than the administered rate of interest that the Federal Reserve sets on excess reserves, then any LCR-driven demand for reserves could be relatively dampened.

So far, we have very little direct information regarding the behavior of banks' underlying demand for excess reserve balances. For example, the aggregate level of reserves in the banking system declined significantly through 2018 , from its peak of $\$ 2.8$ trillion in late 2014 to about $\$ 1.7$ trillion in December 2018, with no significant pressure evident on the various interest rates that one might expect if banks had a strong preference to hold on to those reserve balances.

We next consider bank-level data to see how individual banks' compositions of HQLA have evolved in recent years.

\section{WHAT DO INDIVIDUAL BANK-LEVEL DATA SHOW?}

To get an understanding of how individual large banks have been managing their liquidity needs post crisis, we look at bank-level data for the eight U.S. GSIBs. First we examine the longer-run trends in their holdings based on our quarterly estimates of HQLA. Then we consider high-frequency daily movements in these holdings by utilizing a relatively new, confidential supervisory data set collected via the Federal Reserve's FR 2052a described in our data appendix.

At the end of 2017, the eight GSIBs together held more than \$2 trillion of aggregate HQLA and represented more than 80 percent of the total assets of standard LCR banks (those shown in Figure 1). Figure 5 displays the composition of each of these eight institution's HQLA, with the institutions ordered by dollar amount of HQLA holdings, largest to smallest from left to right. The red vertical lines indicate when each institution publically announced it had fully met its LCR requirement (that is, had a ratio of at least 100 percent). As shown, in the run-up to meeting the LCR, about half of these banks relied heavily on reserves (blue bar portions), while others relied on a wider range of assets.

However, after becoming compliant, most banks that had relied heavily on reserves exhibit a decline in such reliance, albeit to varying degrees. Such adjustments are consistent with banks subsequently aiming to improve the risk-return trade-off associated with their HQLA portfolios and determining that fewer reserves were needed to meet their liquidity needs.

Data through 2017:Q4 show that each of these large banks appears to have since settled into relatively stable shares of HQLA, and, across institutions, they display a wide range of reserve (risk-free asset) shares of HQLA - from as little as around 20 percent or less for about half of the institutions to above 50 percent. Even the four largest holders of HQLA, often cat- 


\section{Figure 5}

\section{Individual Banks' HQLA Shares}

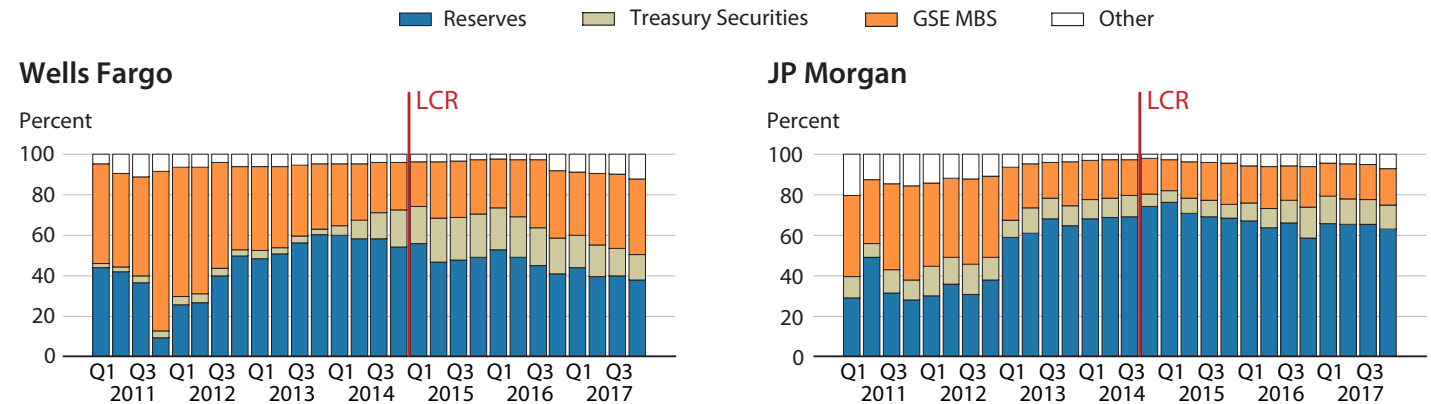

\section{Bank of America}
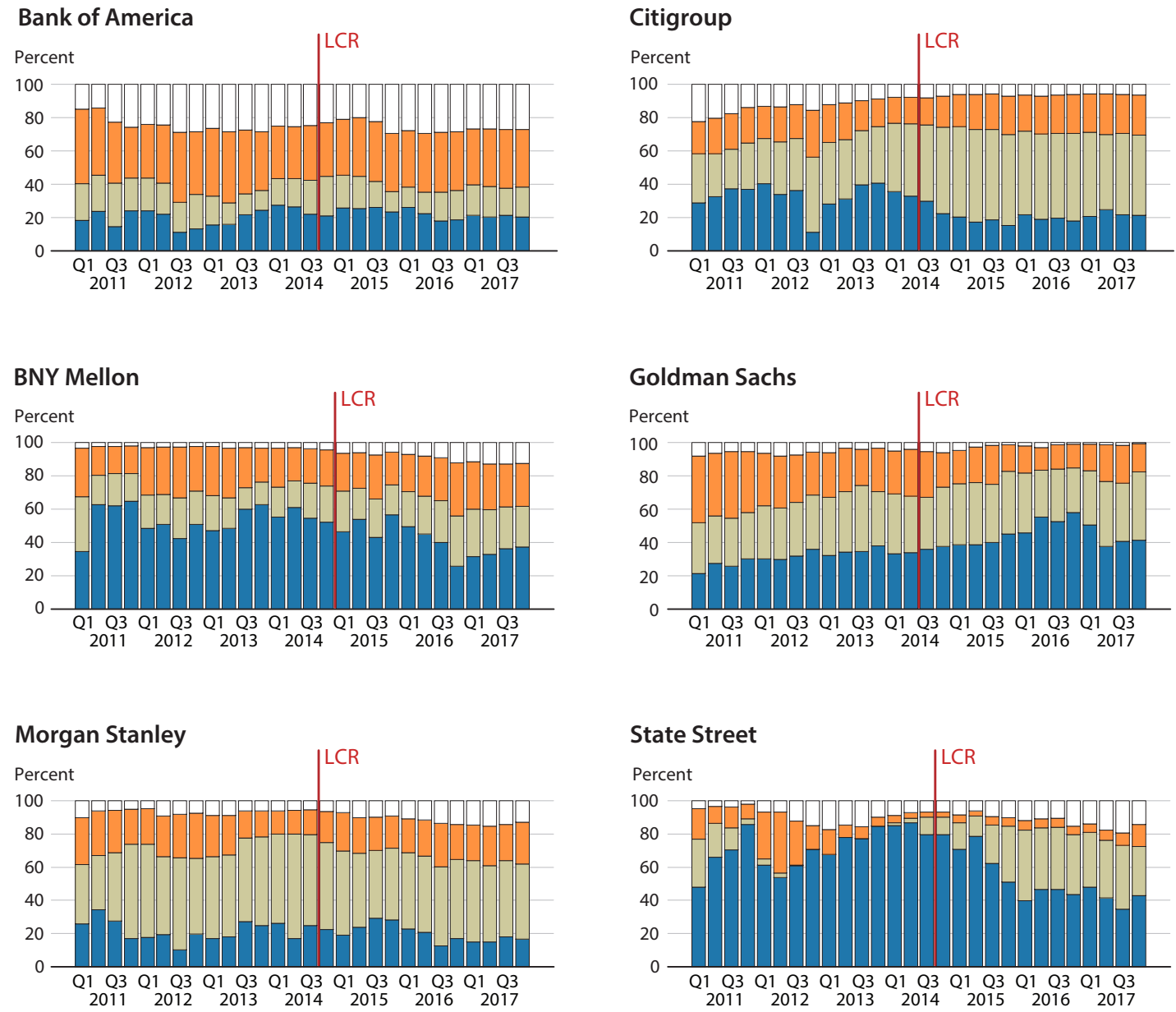

NOTE: Security balances based on fair value of AFS, HTM, and trading account securities. Other HQLA include GNMA MBS, agency CMBS, and agency debt. Red lines indicate quarter in which bank publicly stated it met the fully phased-in final U.S. LCR rule based on its own calculations. SOURCE: Call reports (for reserves, or balances held at Federal Reserve Banks; FFIEC 031/041), FR Y-9C (all other data), and transcripts from quarterly earnings calls and financial updates (red lines). 
Figure 6

Daily Variance of Banks' HQLA Shares Post LCR (January 2015-March 2017)

Standard Deviation (Daily Share of HQLA; percentage points)

30
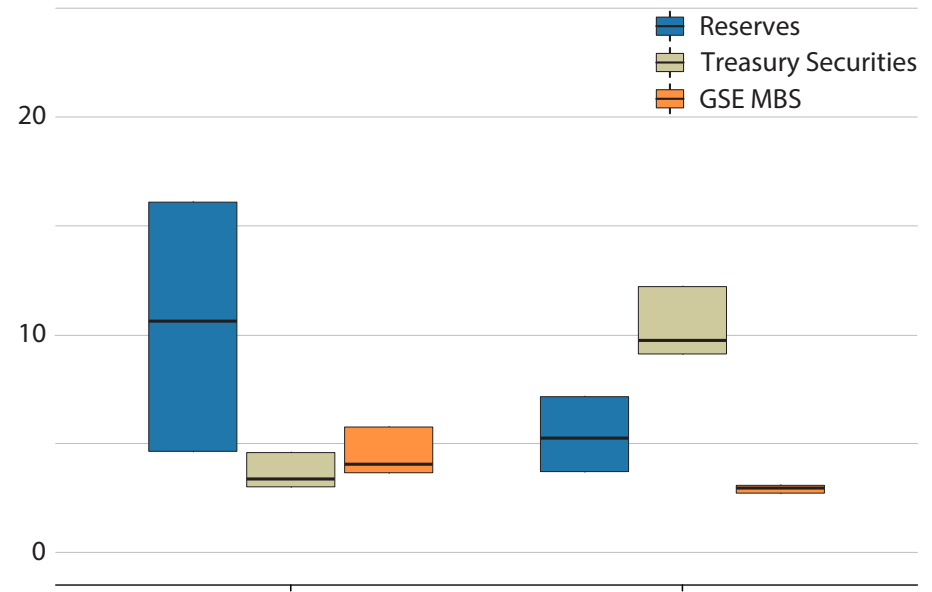

High Reserves Share Low Reserves Share

NOTE: "High Reserves Share" banks comprise the four GSIBs with the highest average shares of reserves to HQLA, and "Low Reserves Share" banks comprise the remaining four banks. The horizontal line through each bar is the median bank's standard deviation; the high and low ends of each bar signify the 75th and 25th percentiles, respectively. (With four observations in each bank group, medians and percentiles are the midpoint [average] of the appropriate neighboring observations.)

SOURCE: FR 2052a.

egorized as universal banks, are noticeably dissimilar in their compositional choices: Wells Fargo relies mainly on a mix of reserves and GSE MBS; JP Morgan mainly reserves; Bank of America mainly GSE MBS; and Citigroup mainly Treasury securities. The two investment banks, Goldman Sachs and Morgan Stanley, also exhibit very different compositions.

Turning to the daily movement in the GSIBs' individual HQLA shares, we compute the average daily standard deviation of each institution's reserves, Treasury securities, and GSE MBS shares. As shown in Figure 6, we divide the sample into two equal-sized bank groupsthose with relatively high reliance on reserve balances (left-hand bars) and those with relatively low reliance on reserve balances (right-hand bars). $\underline{20}$ Overall, we find that banks that experience higher daily variance in their cash balances tend to hold more cash. As shown by the left-most blue bar, the median share of reserves that comprises reserve-reliant institutions' HQLA varies day-to-day by about 10 percentage points and the interquartile dispersion runs from 5 to 15 percentage points on any given day. Meanwhile, the shares of these banks' Treasury securities (left-most green bar) and MBS (left-most orange bar) are significantly more stable. In contrast, as shown by the right-hand set of bars, banks with much less variation in their reserves share exhibit relatively low reliance on reserve balances; for these insti- 
tutions, the highest average daily variation in HQLA shares is in the Treasury share. $\underline{21}$ Next we explore what can be driving these and other differences across the GSIBs.

\section{WHAT EXPLAINS THE DISPARATE BEHAVIOR OF BANKS' HQLA SHARES?}

In terms of our model, the question is, what in $A$ is driving the large differences in banks' HQLA shares and in their reserves shares in particular? A number of considerations appear to be in play and, for the largest banks at least, we conclude that the answer largely varies by institution. We attribute this result to three factors.

First, as was their intent, post-crisis financial regulations are affecting banks' liquidity management. The LCR is a predominant example, but it is important to remember that banks' resolution planning and capital management also affect their liquidity management. Respondents to the Senior Financial Officer Survey ranked internal liquidity stress tests, which are used in resolution planning, as the most significant factor affecting their demand for reserves. In an internal stress test, a bank that deems it difficult to raise large-scale funds quickly by engaging in sufficiently sizable repos or by conducting sufficiently sizable outright asset sales, may lean toward holding a relatively abundant level of reserves for precautionary reasons. $\underline{22}$ Indeed, in 2017 Citigroup pointed to its resolution planning as an important cause for growth in its cash balance. $\frac{23}{.}$ Furthermore, capital constraints can also influence banks' choice of HQLA holdings. A bank with an effectively binding risk-based capital ratio would likely lean, on the margin, toward onboarding additional reserve balances and Treasury securities to meet its HQLA requirement because those assets carry a zero risk weight.

Second, observable factors, including a bank's business model and the particular products and services it offers, importantly help determine a bank's liquidity needs and drive its internal preferences for certain quantities and types of liquid assets. For example, a bank that engages in significant payment, settlement, and clearing activities may desire a relatively high share of reserve balances to meet its intraday and next-day liquidity needs, especially since the timing of many payments has recently shifted to earlier in the day, when settlements for repo transactions would not be available. ${ }^{24}$ These factors would likely hold for large processing banks such as BNY Mellon and State Street. Other business factors that may boost demand for reserves include commercial lending activities and retail client credit lines such as credit cards and home equity lines of credit. These customer accounts can be unpredictably tapped, suggesting that banks providing such services may prefer certain quantities and types of liquid assets. And those that manage significant amounts of volatile deposits from institutional clients may prefer holding a relatively high share of cash balances to accommodate such variation. $\underline{25}$ Moreover, relative to pre-crisis times, reserve balances now earn interest, reducing the opportunity cost of holding such balances.

Finally, a third factor is unobservable, internal business preferences. Given that the two GSIB investment banks face similar business models and regulations but differ significantly in their preferences for cash holdings, we conclude that these banks' compositional HQLA choices are driven by unobservable, internal business preferences. In particular, banks' self- 
imposed operational cash targets may be established by internal liquidity stress tests; for example, JP Morgan disclosed that an internal duration target is important in driving its HQLA management. $\stackrel{26}{ }$ Limiting the duration of a securities portfolio is an example of how banks actively manage interest rate risk, consistent with our portfolio model.

Overall, the LCR is only one constraint that banks face when choosing their optimal holdings of HQLA. Several other factors are importantly driving banks' liquidity management. How the various factors interact in determining banks' demand for reserves-and the relative importance of each factor in so doing-is complicated by the fact that banks prioritize these factors differently, resulting in a range of HQLA portfolios.

\section{CONCLUSION}

The LCR is a post-crisis liquidity requirement that has importantly affected banks' balance sheet management, research about which is only recently emerging. Our work contributes to the discussion by constructing time-series data to document how U.S. banks have managed the compositions of their HQLA over recent years and by providing a theoretical framework to model banks' preferences for the composition of their HQLA. We empirically documented how banks' HQLA holdings have evolved over time. We explained banks' decisions in the context of our model, which highlights that a bank's demand for reserves is sensitive to the opportunity cost of holding such balances as well as to its aversion to liquidity and interest rate risks. Overall, the more risk averse (tolerant) a bank is, the higher (lower) its demand for reserves.

Looking at the data we created to study both the compositions of banks' HQLA shares and the patterns of daily volatilities of those shares, we documented that banks' individual preferences for HQLA shares vary widely, even for banks with seemingly similar business models. We conclude that banks' liquidity management practices-and thus their underlying sensitivities to liquidity and interest rate risks-are likely driven by a range of considerations that may be grouped into three broad categories: considerations pertaining to liquidity and capital regulations, including the LCR and resolution planning; observable factors such as product lines and business models; and unobservable considerations related to banks' individual business practices and preferences.

We also explained why understanding banks' post-crisis liquidity management practices is important for both the implementation and the transmission of monetary policy. Going forward, the Federal Reserve will need to monitor total reserves in the banking system and decide if the level is "ample" for effective and efficient monetary policy implementation. Careful monitoring of large banks' management of HQLA, and in particular their demand for reserves, will be important in this process. 


\section{DATA APPENDIX}

Here we detail the data sources, methods, and assumptions used to construct each of the bank-level HQLA estimates used in our article.

\section{Quarterly Bank-Level HQLA Estimates}

Our quarterly HQLA time series is based on publicly available data. Our data sources include quarterly regulatory filings, some of which are reported at the commercial bank (depository institution) level; when this was the case, we subsequently mapped individual commercial banks to their affiliated (parent) BHC. These sources included the following:

- Consolidated Financial Statements for Holding Companies (FR Y-9C) from which we obtained individual BHCs' securities holdings, including investment securities and securities in the banks' trading accounts. The FR Y-9C reporting form and instructions are available on the Board of Governors of the Federal Reserve System's website: https://www.federalreserve.gov/apps/reportforms/reportdetail.aspx?sOoYJ+5BzDal8cbqnRxZRg==.

- Consolidated Reports of Condition and Income for a Bank with Domestic Offices (FFIEC 041) and Domestic and Foreign Offices (FFIEC 031) for data on reserve balances. The FFIEC 031 and 041 forms and instructions are available on the FFIEC's website: https://www.ffiec.gov/ffiec report forms.htm.

For simplicity and because of some data limitations, we made the following methodological choices in constructing our quarterly bank-level HQLA estimates:

- We ignored LCR-eligible HQLA assets outside of the seven asset categories listed in Table 1, including banks' holdings of Level 2B assets such as corporate debt. Banks generally hold relatively small shares of such assets, making our conclusions robust to their exclusion. For example, for the eight GSIBs we examined in detail, less than 2 percent of their HQLA consisted of Level 2B assets in the second quarter of 2017, as reported in their first required public LCR disclosures.

- We used data on banks' total reserve balances instead of excess reserves, but these measures differ little in aggregate over the period we primarily study. According to the Federal Reserve's H.3 statistical release, Aggregate Reserves of Depository Institutions and the Monetary Base, required reserves in the banking system totaled about $\$ 160$ billion on average in February 2017, while total reserves averaged about \$2,300 billion.

- For Figures 1 and 2, we ignored Level 2 asset caps (described in the main text); however, most BHCs are not near those caps. The share allocations in our risk-return model analysis did account for the caps.

- Due to limitations of the granularity of the publicly available data, some non-GSE agency securities (Level 1 assets) are included in our estimates of the GSE asset (Level 2A) categories. However, for very large banks, we think our HQLA asset category estimates are reasonable. For example, for the eight GSIBs examined, we estimate that use of the 


\section{Table A1}

\section{Construction of Quarterly Bank-Level HQLA Estimates from Public Sources}

\begin{tabular}{|c|c|}
\hline HQLA component & Calculation \\
\hline Reserves & FFIEC 031/041 RC-A item 4 \\
\hline Treasury securities & $\begin{array}{l}\text { FR Y-9C HC-B item } 1 \text { (column B) + Item } 1 \text { (D) } \\
+ \text { HC-D item } 1(A)\end{array}$ \\
\hline GNMA MBS & FR Y-9C HC-B item 4.a.(1) (B) + Item 4.a.(1) (D) \\
\hline Non-GSE agency debt & FR Y-9C HC-B item 2.a (B) + Item 2.a (D) \\
\hline GSE debt & $\begin{array}{l}\text { FR Y-9C HC-B item 2.b (B) + Item 2.b (D) } \\
+ \text { HC-D item } 2(A)^{\dagger}\end{array}$ \\
\hline GSE MBS & $\begin{array}{l}\text { FR Y-9C HC-B item 4.a.(2) (B) + Item 4.a.(2) (D) } \\
+ \text { Item 4.b.(1) }(B)^{\dagger}+\text { Item 4.b.(1) (D) }{ }^{\dagger} \\
+ \text { HC-D item 4.a }(A)^{\dagger}+\text { Item 4.b (A) }\end{array}$ \\
\hline Agency CMBS & $\begin{array}{l}\text { FR Y-9C HC-B item 4.c.(1)(a) (B) }{ }^{\dagger}+\text { Item 4.c.(1)(a) (D) } \\
+ \text { Item 4.c.(2)(a) }(B)^{\dagger}+\text { Item 4.c.(2)(a) (D) } \\
+ \text { HC-D item 4.d }(A)^{\dagger}\end{array}$ \\
\hline
\end{tabular}

NOTE: ${ }^{\dagger}$ Includes obligations of both U.S. government agencies and U.S. GSEs.

publicly available data results in about 80 percent of banks' Level 1 assets sorted accurately, with the remaining 20 percent inaccurately included in our GSE (Level 2A) asset categories.

- Finally, also due to data limitations, we ignored whether the securities included in our HQLA estimates were deemed by each bank to be "unencumbered" or not (the LCR requires securities be unencumbered, that is, free of legal, regulatory, contractual or other restrictions on the ability of the bank to liquidate, sell, transfer, or assign the assets). We do not believe that making such a generality has biased our findings or conclusions.

In Table A1, we list each of the specific line items that we used to construct quarterly HQLA using these publicly available data sources. Given that the LCR requirement is based on assets valued at market values, the fair-value measures of banks' securities holdings are used (as reported on schedule HC-B for both available-for-sale [AFS] and held-to-maturity [HTM] securities).

\section{Daily Bank-Level HQLA Estimates}

To construct our daily bank-level measures, we used two sources of confidential micro data collected by the Federal Reserve:

- For historical data on individual banks' reserve balances, we relied on the confidential flows associated with the Report of Transaction Accounts, Other Deposits and Vault Cash (FR 2900). FR 2900 reporting forms and instructions are available on the Board's website: https://www.federalreserve.gov/apps/reportforms/reportdetail.aspx?sOoYI+5BzDbli7g2+r203S0gg6NcUIj6. 
- For daily data on HQLA reported directly by BHCs, we relied on the confidential supervisory data collected from the Complex Institution Liquidity Monitoring Report (FR 2052a). This form is collected from U.S. GSIBs-those with $\$ 700$ billion or more in consolidated assets or with $\$ 10$ trillion or more in assets under custody. These BHCs submit a report each business day and have been doing so since December 14, 2015; prior to that time, beginning in 2012, these BHCs submitted more-limited daily data. The FR 2052a data comprise the detailed balance sheet inputs necessary to calculate the LCR, but do not include the actual LCR ratios or the numerators and denominators of the ratios. FR 2052a reporting forms and instructions are available on the Board's website: https://www.federalreserve.gov/apps/reportforms/reportdetail.aspx?sOoYJ+5BzDbpqbklRe3/1zdGfyNn/SeV.

These source data for the daily measures of HQLA are quite limited prior to December 2015-they consist of reserves, Level 1 HQLA (which include reserves), and (total) Level 2 HQLA. Because we are interested in tracking banks' behavior over the past several years, we created separate proxy measures for banks' Treasury securities and GSE MBS holdings, as follows: For the period in which insufficiently detailed data are available, we assumed that each of the following two relationships held:

$$
\text { Treasury securities }=\text { Level } 1 \text { assets }- \text { Total reserves }
$$

$$
\text { GSE MBS = Level } 2 \text { assets. }
$$

For robustness checks, we first compared each proxy share to the corresponding actual measure using data for 2016, when both measures are available. The performance of our Treasury proxy is somewhat mixed, while that of our MBS proxy seems quite accurate. Two banks largely account for the miss in the Treasury proxy, one with large GSE debt holdings and one with a large portion of encumbered (thus ineligible for the LCR) Treasury holdings. Second, we considered whether the proxies and actual measures behaved similarly in terms of the daily standard deviations. Our proxy shares exhibit volatilities that are similar to those of the actual ratios. 


\section{Ihrig, Kim, Vojtech, Weinbach}

\section{NOTES}

1 Our analysis focuses on banks' management of the numerator of the LCR—banks' adjustments to the compositions of their holdings of HQLA. We recognize that to implement and manage the LCR requirement, banks also make adjustments to balance sheet liabilities, which feed back into the calculation of necessary HQLA. Abstracting from the denominator does not affect our analysis.

$\underline{2}$ For an overview of how liquidity regulations are affecting demand for reserves, see Ihrig (2019). This factor is influencing the FOMC's determination of ample reserves as seen in the Federal Open Market Committee's March Press Release "2019 Balance Sheet Normalization Principles and Plans" available here: https://www.federalreserve.gov/newsevents/pressreleases/monetary20190320c.htm. Also, see Quarles (2018) for an overview of how large banks' reserve demand interacts with the size of the Federal Reserve's balance sheet.

$\underline{3}$ The BCBS is a committee of banking supervisory authorities that was established by the central bank governors of the G10 countries in 1975. The Office of the Comptroller of the Currency, Board of Governors of the Federal Reserve System, and Federal Deposit Insurance Corporation (FDIC) actively participate in the BCBS and its international efforts. Documents issued by the BCBS are available through the Bank of International Settlements website: http://www.bis.org/. The BCBS's description of the LCR may be found here: http://www.bis.org/publ/ bcbs238.pdf. Information about the Basel III framework may be found here: http://www.bis.org/bcbs/basel3.htm.

4 The text of the final U.S. LCR rule, issued in September 2014, may be found here: https://www.federalreserve.gov/ newsevents/pressreleases/bcreg20140903a.htm. For a descriptive overview of the LCR rule, see House, Sablik, and Walter (2016). Of course, the LCR is not the first incidence of liquidity regulation of U.S. financial institutions. Reserve requirements of depository institutions, administered by the Federal Reserve, were originally implemented as a prudential requirement to promote banks' liquidity positions. However, the prevalence of banks' retail deposit sweep programs, begun in the mid-1990s, meant that reserve requirements were not commonly a binding consideration for most large banks prior to the Financial Crisis. See Bouwman (2015) for a synthesis of the theoretical and empirical literature on the economics of how banks create liquidity and of related issues regarding liquidity requirements. A historical overview of liquidity regulation, ending with Basel III and the Dodd-Frank Act, is also provided.

5 When the largest banks began publicly disclosing their LCR-related data for the quarter ending June 30, 2017, Bank of America, Citigroup, JP Morgan, and Wells Fargo each reported that Level 2B assets made up less than 1 percent of their total HQLA. LCR-related disclosure requirements for U.S. banks are described here: https://www.federalreserve.gov/newsevents/pressreleases/bcreg20161219a.htm.

6 The original requirements for meeting the standard versus the modified LCR rule are as follows: Banks subject to the standard LCR requirement have $\$ 250$ billion or more in total consolidated assets or $\$ 10$ billion or more in on-balance sheet foreign exposure, or are these banking organizations' subsidiary depository institutions with assets of $\$ 10$ billion or more. Banks that do not meet these thresholds but have $\$ 50$ billion or more in consolidated assets are subject to the modified LCR requirement; the denominator of the modified LCR is multiplied by 70 percent. After the time period we analyze, the $\$ 50$ billion threshold was raised to $\$ 100$ billion by the Economic Growth, Regulatory Relief, and Consumer Protection Act in May 2018. More information is available in the related press release found here: https://www.federalreserve.gov/newsevents/pressreleases/bcreg20180706b.htm.

1 The U.S. LCR was phased in as follows: Standard LCR banks were required to maintain an LCR of 80 percent beginning in January 2015, all LCR banks were required to maintain a 90 percent ratio beginning in January 2016, and full compliance-a ratio of 100 percent or more—was required beginning in January 2017.

$\underline{8}$ As we describe in our data appendix, for simplicity we use data on banks' total reserve balances instead of excess reserves because these measures differ little in aggregate over the period we primarily study.

9 For an explanation of the mechanism by which increases in the Federal Reserve's security holdings, such as via LSAPs, resulted in a commensurate increase in the amount of reserve balances in the banking system, see the data appendix to Ihrig, Meade, and Weinbach (2015a or 2015b).

10 While the Federal Reserve was holding the size of its securities holdings constant over this period, the aggregate stock of reserves in the banking system was declining, reflecting the ongoing growth in the outstanding stock of currency in circulation. That said, these banks' reserve holdings did not decline in proportion to the aggregate drop in reserve supply. In fact, Ihrig, Milchanowski, and Detering (2019) show that the vast majority of the decline in aggregate reserves can be accounted for by declines in the reserve balances of regional banks without LCR 
restrictions, implying that large, LCR-restricted banks intentionally chose to retain reserve balances in their HQLA holdings.

11 The bank treasurer we model must also account for credit risk, which we assume to be small in this context.

12 Under Basel III, some BHCs must include net unrealized gains and losses from available-for-sale (AFS) securities in their calculation of the common equity tier 1 capital to risk-weighted assets ratio. For such institutions, changes in the valuation of AFS securities add volatility to their capital ratios. While both AFS and held-to-maturity (HTM) securities qualify as HQLA, only AFS securities can be immediately sold without accounting rule penalties. There has been a notable increase in the share of HTM securities at large banks since 2011, thus reducing the impact of interest rate risk on the regulatory capital of such banks.

13 Treasuries and MBS also carry some credit risk, which as noted we abstract from. For example, in August 2011, Standard \& Poor's downgraded the credit rating of U.S. Treasury debt from AAA to AA+ shortly after Congress voted to raise the debt ceiling of the federal government by means of the Budget Control Act of 2011.

14 For example, in a 2017:Q4 earnings call (S\&P Global, 2018), Citigroup's treasurer noted, "we're constantly looking at the optimization within HQLA, which is cash and HQLA securities, but then also looking at are there other investment opportunities that makes sense? ... As obviously, [how] the interest rate environment changes or the spread environment changes [is] something we're constantly focused on and evaluating in terms of how to optimize."

15 For simplicity, our analysis ignores the trade-offs banks face in choosing among various maturities of Treasury securities and MBS. Given that rates of return are not perfectly correlated, the choice of the maturities of the assets considered does affect the estimated shares. For example, if in the last row of Table 2 a 2-year Treasury security is considered instead of a 5-year Treasury security (column 2), the optimal reserves share (column 4) rises from 0 to 16 percent (with the shares of Treasury securities and MBS falling to 50 and 34 percent, respectively). In addition, as already noted, for simplicity our analysis ignores other HQLA-eligible assets that are held in much smaller shares.

16 It is difficult to benchmark our coefficient of relative risk aversion, $A$, to values, or a range of values, that might be representative in our context. The coefficient is mostly used in the risk aversion literature for households; see Grandelman and Hernández-Murillo (2014) for a review. While the most commonly accepted estimates in that context lie between 1 and 3, a wide range of estimates have been presented-from as low as 0.2 to 10 and higher. Thus, we examine a wide range of parameter values.

17 We do not account here for the 15 percent haircut that is applied to banks' holdings of GSE MBS; doing so in this scenario would result in banks holding even more MBS to achieve the 60-40 portfolio. We exclude the haircut in our portfolio model because it is not straightforward to adjust the relative yields we consider to reflect such a constraint.

18 Setting the return on reserves equal to the effective federal funds rate over the entire sample period_-including the early portion of this sample period-may constitute a return that was higher at times than in practice, which would upwardly bias the resultant reserve balance shares derived from our model. More generally, standard models of the federal funds market show that an increase in the rate at which federal funds are remunerated decreases the opportunity cost of holding reserves, suggesting that banks would demand more reserve balances as the remuneration rate rises (see Figure 5 of Ihrig et al., 2015a).

19 A summary of the survey findings can be found here: https://www.federalreserve.gov/data/sfos/files/senior-financial-officer-survey-201809.pdf.

$\underline{20}$ Because the source data are confidential, we cannot show our individual, bank-level estimates of HQLA at the daily frequency.

21 We do not find it surprising that the GSIBs' MBS shares, the orange bars in Figure 6, exhibit relatively little daily volatility for each bank group. Because MBS are less liquid than Level 1 assets and subject to duration risk and eligible MBS holdings are capped under the LCR, banks likely largely position their MBS holdings at a desirable level and do not seek to adjust this component on the margin, at a high frequency. As evidence of this, GSIBs have a much higher share of their MBS holdings booked as HTM (that is, not AFS) than they do Treasuries-about 30 percent versus 20 percent, respectively.

$\underline{22}$ See Andolfatto and Ihrig (2019) for a summary of how resolution planning in particular may be causing banks to hold sizable reserve balances in the current economic environment. 


\section{Ihrig, Kim, Vojtech, Weinbach}

$\underline{23}$ Citigroup in its 2017:Q4 fixed income call (S\&P Global, 2018) responded to a question about growth in its liquid assets by saying that its resolution planning "caused... growth in [its] liquidity balance, especially cash... in the first half of [2017]."

24 See Bech, Martin, and McAndrews (2012) for evidence that banks' payment flows have moved to earlier in the day.

$\underline{25}$ Indeed, a majority of the respondents to the Senior Financial Officer Survey indicated that meeting potential deposit outflows was an important or very important determinant of their reserve demand.

$\underline{26}$ In an earnings call with market analysts, JP Morgan responded to a question about why it held so many excess reserves rather than higher-yielding assets such as MBS by pointing out that it already has high mortgage exposure taking both its mortgage loans and MBS holdings into account, and that further increasing its MBS holdings to augment returns would cause it to exceed its internal duration target (Thomson Reuters StreetEvents, 2017).

\section{REFERENCES}

Andolfatto, David and Ihrig, Jane. "Why the Fed Should Create a Standing Repo Facility." Federal Reserve Bank of St. Louis On the Economy Blog, March 6, 2019; https://www.stlouisfed.org/on-the-economy/2019/march/why-fed-create-standing-repo-facility.

Adrian, Tobias and Boyarchenko, Nina. "Liquidity Policies and Systemic Risk." Staff Report No. 661, Federal Reserve Bank of New York, 2013; https://doi.org/10.2139/ssrn.2377451.

Allen, Franklin. "How Should Bank Liquidity Be Regulated?" Speech at the Federal Reserve Bank of Atlanta, March 27, 2014; https://www.frbatlanta.org/-/media/Documents/news/conferences/2014/fmc/Allen.pdf.

Balasubramanyan, Lakshmi and VanHoose, David D. "Bank Balance Sheet Dynamics under a Regulatory LiquidityCoverage-Ratio Constraint." Journal of Macroeconomics, 2013, 37, pp. 53-67; https://doi.org/10.1016/j.jmacro.2013.03.003.

Banerjee, Ryan N. and Mio, Hitoshi. "The Impact of Liquidity Regulation on Banks." Staff Working Paper No. 536, Bank of England, 2015; https://doi.org/10.2139/ssrn.2635522.

Bech, Morten and Keister, Todd. "Liquidity Regulation and the Implementation of Monetary Policy." Journal of Monetary Economics, 2017, 92, pp. 64-77; https://doi.org/10.1016/j.jmoneco.2017.09.002.

Bech, Morten; Martin, Antoine and McAndrews, Jamie. "How the High Level of Reserves Benefits the Payment System." Federal Reserve Bank of New York Liberty Street Economics, February 27, 2012; https://libertystreeteconomics.newyorkfed.org/2012/02/how-the-high-level-of-reserves-benefits-the-paymentsystem.html.

Bianchi, Javier and Bigio, Saki. "Banks, Liquidity Management, and Monetary Policy." Staff Report 503, Federal Reserve Bank of Minneapolis, 2017; https://www.minneapolisfed.org/research/sr/sr503.pdf.

Bouwman, Christa H.S. "Liquidity: How Banks Create It and How It Should Be Regulated," in Allen N. Berger, Philip Molyneux, and John O.S. Wilson, eds., The Oxford Handbook of Banking. Oxford University Press, 2015, 2nd Ed., pp. 184-218.

Cetina, Jill and Gleason, Katherine I. "The Difficult Business of Measuring Banks' Liquidity: Understanding the Liquidity Coverage Ratio." Working Paper No. 15-20, Office of Financial Research, 2015; https://doi.org/10.2139/ssrn.2681372.

Cuoco, Domenico and Liu, Hong. "An Analysis of VaR-Based Capital Requirements." Journal of Financial Intermediation, 2006, 15, pp. 362-94; https://doi.org/10.1016/j.jfi.2005.07.001.

Covas, Francisco and Driscoll, John C. "Bank Liquidity and Capital Regulation in General Equilibrium." Finance and Economics Discussion Series 2014-85, Board of Governors of the Federal Reserve System, 2014; https://www.federalreserve.gov/econresdata/feds/2014/files/201485pap.pdf.

Diamond, Douglas W. and Kashyap, Anil K. "Chapter 29 - Liquidity Requirements, Liquidity Choice and Financial Stability," in John B. Taylor and Harald Uhlig, eds., Handbook of Macroeconomics. Volume 2. Elsevier, 2016, pp. 2263-303; https://doi.org/10.1016/bs.hesmac.2016.03.011. 
Duffie, Darrell and Krishnamurthy, Arvind. "Passthrough Efficiency in the Fed's New Monetary Policy Setting." Working paper presented at the 2016 Jackson Hole Symposium of the Federal Reserve Bank of Kansas City, 2016; https://www.kansascityfed.org/ /media/files/publicat/sympos/2016/econsymposium-duffie-krishnamurthy-paper.pdf?la=en.

Grandelman, Néstor and Hernández-Murillo, Rubén. "Risk Aversion at the Country Level." Working Paper 014-005B, Federal Reserve Bank of St. Louis, October 2014; https://s3.amazonaws.com/real.stlouisfed.org/wp/2014/2014-005.pdf.

Halaj, Grzegorz. "Optimal Asset Structure of a Bank: Bank Reactions to Stressful Market Conditions." Working Paper Series No. 1533, European Central Bank, April 2013.

Halaj, Grzegorz. “Dynamic Balance Sheet Model with Liquidity Risk." Working Paper Series No. 1896, European Central Bank, April 2016; https://doi.org/10.2139/ssrn.2625983.

House, Mark; Sablik, Tim and Walter, John. "Understanding the New Liquidity Coverage Ratio Requirements." Economic Brief EB16-01, Federal Reserve Bank of Richmond, 2016.

Ihrig, Jane E. "Banks' Demand for Reserves in the Face of Liquidity Regulations." Federal Reserve Bank of St. Louis On the Economy Blog, March 5, 2019.

Ihrig, Jane E.; Milchanowski, Mike and Detering, Jennifer. "Which Banks Have Been Shedding Reserves?" Federal Reserve Bank of St. Louis On the Economy Blog, April 18, 2019; https://www.stlouisfed.org/on-the-economy/2019/april/bank-shedding-reserves.

Ihrig, Jane E.; Meade, Ellen E. and Weinbach, Gretchen C. "Monetary Policy 101: A Primer on the Fed's Changing Approach to Policy Implementation." Finance and Economics Discussion Series 2015-047, Board of Governors of the Federal Reserve System, 2015a; https://doi.org/10.17016/FEDS.2015.047.

Ihrig, Jane E.; Meade, Ellen E. and Weinbach, Gretchen C. "Rewriting Monetary Policy 101: What's the Fed's Preferred Post-Crisis Approach to Raising Interest Rates?" Journal of Economic Perspectives, 2015b, 29(4), pp. 177-98; https://doi.org/10.1257/jep.29.4.177.

Quarles, Randal K. "Liquidity Regulation and the Size of the Fed's Balance Sheet." Presented at "Currencies, Capital, and Central Bank Balances: A Policy Conference," Stanford University, May 4, 2018.

S\&P Global Market Intelligence. "Citigroup Inc. Fixed Income Call." January 24, 2018, accessed through SNL Financial.

Thomson Reuters StreetEvents. "Edited Transcript: JPM - Q3 2017 JPMorgan Chase \& Co Earnings Call." October 12, 2017, accessed through SNL Financial. (Presentation available at https://www.jpmorganchase.com/corporate/ investor-relations/quarterly-earnings.htm.) 
